\title{
Mexico: The Rabbit's Navel
}

\section{Gutierre Tibón ${ }^{1}$}

\begin{abstract}
The toponym Mexico has long been etymologized as "the navel of the moon." This anatomical image has been supported by recent research which identifies the positions of the early lakes on the present site of Mexico City, showing a pattern similar to that perceived on the moon, in both cases resembling a rabbit. Aztec priests searched for a long time to locate an island on which to build a temple. The island, Tenochtitlan, is in a position corresponding to the navel of the rabbit.
\end{abstract}

\section{$* * * * *$}

Toponymic studies often present difficulties requiring knowledge of other disciplines such as history, the study of symbols, and mythology. In dealing with placenames of American Indian origin, the more advanced the culture the more complex the problems the researcher must confront, for some etymologies-acceptable on the surface-even predate the period of European conquest.

For the toponym Mexico, in which the name of the ancient capital city of a Mesoamerican empire becomes that of one of the great nations of our hemisphere as well as the name of one of the fifty United States, there exist some seventy-one different etymologies, of which only one is the true one. This is demonstrated by the fact that the meaning of the word Mexico is identical in meaning in several indigenous languages, such as Mixtec, Otomí, Pame, and Tarasco. This is the same phenomenon we can observe in European languages. For example, the African republic known in English as the Ivory Coast is known in Spanish as Costa de Marfil, in French as Côte d'Ivoire, in Italian as Costa d'Avorio, and in German as Elfenbeinküste. Evidently, the comparative versions in Mesoamerican languages represent the first step in penetrating the arcane sense of names whose meaning seems absolutely cryptic.

The common assumption about the etymology of Mexico is that it comes from three words of the Náhuatl (Aztec) language, as follows: Metz(tli) 'moon,' xic(tli) 'navel,' and co 'in,' thus Metzxicco 'in the navel of the moon.' 
I have dedicated forty years of research to codices prepared both before and after the Hispanic conquest, documents developed by Náhuatl and Spanish historians, in order to penetrate a magical-religious world that justifies and explains an appellation so far removed from our European understanding.

The second syllable, xic (pronounced [shrk]), signifies "navel," which, as in European languages, also is the equivalent of "center." It follows logically that the capital of an empire is considered its central point, its navel. The center of the Greek world was Delphi, represented by an omphalos stone, freely sculptured. The capital of the Aztec empire was consecrated to the sun in its denomination of Huitzilopochtli, a name which means "left-handed hummingbird."

What does the moon have to do with this? According to Aztec myth, the journey from Aztlan, or Aztlan Aztatlan, ancient capital of the kingdom of the same name (in Nayarit) to the Valley of Mexico was directed by this very Huitzilopochtli and his sister Malinal Xóchitl 'grass flower,' that is, their images, considered as the deities themselves; the goddess manifested herself as the moon. One night, almost at the end of the long journey, the sun god abandoned his sister, who took refuge in Malinalco, a town that has preserved the name of the goddess, today a famous archeological center. Her son Cópil 'royal crown,' another representation of the moon, attempted to incite the people of the Valley to make them destroy the Aztecs in Chapultepec. On the Cerro del Peñon (or Hill of the Big Rock) a mortal fight was waged between Huitzilopochtli (that is, the priest personifying him) and the young Cópil. The latter was defeated and slain by Huitzilopochtli, who told Tenoch (from the tree which produces the tenochtli 'red hard prickly pears,' with its heart-shaped fruit) to run to bury his nephew's heart on a certain islet that the high priests had patiently sought for an entire Aztec century (fifty-two years). There are those who assert that the pristine islet was located on the spot where today stands - in La Plaza de Santo Domingo - the monument to the Corregidora (the mayor's wife), right within the circumference of the Main Temple of the Aztecs. There was no sign of what powerful impulse motivated the mystic searchers in the extremely vast extension of reeds and rushes: a mystery I am about to reveal.

We know that Tenoch buried Cópil's heart on the islet, and that by a miracle the tenochtli, the symbol of human hearts sacrificed to the sun Huitzilopochtli-sprouted from his heart. This miracle also signifies the triumph of the Solar Aztecs over the Lunar Aztecs, loyal followers of 
Malinal Xóchitl, who, because of her maternal instincts, was opposed to human sacrifice. This was the site indicated by Huitzilopochtli to establish the capital of the Aztec empire. But how can we, after 636 years, without documents to guide us, discover its exact location? What inspired the choice of that spot among so many thousand?

At this point, it is absolutely necessary to recall that the sun and its nahual 'double' the eagle are one entity; that is, their names are interchangeable. In like fashion the moon is identified with its nahual, the rabbit that lives on it. In contrast to the sun, which is all fire, the moon is a place of quiet peace, the home of the rabbit, prolific rodent and symbol of fertility.

The victory of the sun over the moon does not deprive his sister of her role as the one who keeps the waters of the cosmos, sends rain, and preserves the pallid but providential light that the moon provides at night. The moon was worshipped in ancient Mexico in countless temples, the metzcalli 'lunar temples.' Thanks to the "repudiators of idolatry and superstition," Hernando Ruiz de Alarcón (brother of the esteemed Golden Age playwright) and Jacinto de la Serna, we know another metaphor that both authors considered "diabolical": the earth, in conjurings, was called "face-up rabbit, for thou art resplendent mirror..."; that is, the rabbit is the reflection of the earth on heaven or vice versa, and indeed deserves this epithet.

The words Mexicco Tenochtitlan appear on the shield of the nation: the syllable $M e$ - represents the moon, metztli, the rabbit; $x i$ - is $x i c t l i$, the navel or center, represented by the stone on which the tenochtli, the tree of hearts, is supported. The name Tenochtli is immortalized in Tenochtitlán: the syllable tli drops out and it is completed with the placename element -titlan. The sun, the supreme god, is the royal eagle that sits upon the tenochtli, and water, on which rest the most striking moments of the founding of Mexico, is also present in this picture.

The union of all the lakes of the Valley of Mexico, formerly interlinked from Zumpango to Chalco, has the approximate figure of the rabbit "sitting on its hind legs, as it is accustomed to do." In the same way that we can see the moon in the Tropic of Cancer, the ancient fishermen who for centuries navigated along the shores of this lake knew the moon-rabbit in its terrestrial reflection.

The last secret of the name of Mexico, the reason for the extremely long search to discover the site of incalculable sacred meaning, is the navel of the rabbit, a synonym for the moon, as the eagle is for the sun. 
My deduction has become a visible reality, scientifically proven, thanks to the patient and valuable work of the geologist and vulcanologist Federico Mooser and his collaborator, the engineer Enrique Rodríguez Ramírez. The former reconstructed the boundaries and levels of the lakes, some seventy-five uninterrupted kilometers of fresh water and salt water drainage channels that the Spaniards viewed as "an interior sea." Rodríguez Ramírez enriched Mooser's bare maps with geographical names which, except for the imposing Sierra de Guadalupe, preserve their Náhuatl forms. Without the support of these two friends I could not have concluded my investigation begun back in the 1950s.

What really caught engineer Rodríquez Ramírez's attention in the conjurings of ancient Mexico was the multiple insistence with which the metaphorical lunar rabbit is identified with the earth: the object of a detailed study in my History of the Founding of Mexico. Once the lake map was prepared, this engineer discovered that the site of the City of Mexico corresponds with mathematical exactitude to the navel of the rabbit. He generously informed me of his finding, accompanied by a complete map, which permitted me to tie up loose ends. The mystery of the fifty-two years of searching to find the islet amidst the cane fields has been clarified. A singular and unknown aspect of the Aztec myth is thus revealed to us.

At last, without a shadow of doubt, the root and reason for which Mexico is, esoterically, in the navel of the moon appear with radiant clarity.

I dedicate this work as a contribution to the festschrift for my eminent colleague of the American Name Society, Professor Kelsie B. Harder, for whom I wish many more years of profitable activity in our favorite field, the science of names.

Cuernavaca, Morelos, Mexico

\section{Note}

1. Translated from the Spanish by Professor Wayne H. Finke (Executive SecretaryTreasurer of the American name Society), with further assistance from professor Enrique Ollivier, Professor of Spanish at the University of South Dakota. 